\title{
ПЕДАГОГІЧНІ УМОВИ ФОРМУВАННЯ ЕКОЛОГІЧНИХ ЦІННОСТЕЙ МАЙБУТНІХ УЧИТЕЛІВ ПРИРОДНИЧИХ ДИСЦИПЛІН У ПРОЦЕСІ ПРОФЕСІЙНОЇ ПІДГОТОВКИ
}

У статті здійснено теоретичне визначення педагогічних умов формування екологічних иінностей у майбутніх учителів природничих дисииплін. Детермінація вказаних педагогічних умов обгрунтована наявними дослідницькими матеріалами педагогічного спрямування теоретичного та практичного характеру. Обраний дослідницький підхід не лише дозволив обтрунтувати педагогічні умови формування екоцінностей учителів-природничників, а й окреслити методи та засоби їх реалізації в освітньому процесі. Матеріал містить практичні рекомендації щзодо вдосконалення освітніх програм професійної підготовки майбутніх учителів-природничників.

Ключові слова: професійна освіта, педагогічні умови, екологічні ичінності, відношення «Людина Природа».

В статье осуществлено теоретическое обоснование педагогических условий формирования экологических изенностей у будущих учителей естественных дисииплин. Детерминация указанных педагогических условий осуществлена на основании исследовательских материалов педагогического направления теоретического и практического характера. Избранный исследовательский подход не только позволил обосновать педагогические условия формирования экоиенностей учителей-естественников, но и определить методы и средства их реализачии в образовательном проиессе. Материал содержит практические рекомендачии по совершенствованию образовательных программ профессиональной подготовки будущих учителей естественных дисииплин.

Ключевые слова: профессиональное образование, педагогические условия, экологические иенности, отношение «Человек - Природа».

The article suggests a theoretical definition of pedagogical conditions for the formation of environmental values of future teachers of Natural Sciences.

The first stage of the study clarified the essence of such a phenomenon as "pedagogical conditions». The research has showed that the phenomenon of pedagogical conditions has multiple meanings. In the analyzed scientific works, the concept of "pedagogical conditions» covers various aspects of all components of the educational process: goals, content, principles, methods, forms, means, etc. In this research, the term "pedagogical conditions» denotes a set of educational activities implemented by the institution of higher education in the process of professional training. These activities are aimed at forming a system of professional competencies, student's personality development in professional and universal (humanitarian) senses.

Based on the conducted analysis, taking into account theoretical achievements and developments of pedagogical science and practice, generalization of the revealed shortcomings of educational programs concerning preparation of specialists of the corresponding profile, the research defined pedagogical conditions of formation ecological values of future teachers of Natural Sciences in the course of professional training: 1) formation of eco-centric understanding of nature (through the education of future teachers); 2) awareness of environmental values; 3) internal acceptance and ability to transfer and implement environmental values in educational and professional activities.

To increase the validity of the formulation of pedagogical conditions for the formation of environmental values of future teachers of Natural Sciences, the article identifies not only the desired competencies and program learning outcomes, but also the desired positive changes in the future teacher personality due to the formation of professional pedagogical culture, in particular, changes of value, cognitive, and practical nature.

Finally, this research contains practical recommendations for improving the educational programs of professional training of future teachers of Natural Sciences.

Key words: professional education, pedagogical conditions, ecological values, relation "Human - Nature».

Постановка проблеми. Нині людство фактично переживає цивілізаційну кризу у зв'язку з ескалацією глобальних геополітичних, соціоекономічних та екологічних проблем. Буквальне й фізично відчутне зростання негативного змісту відношення «Людина Природа» змушують перспективно й відповідально мислячих людей порушувати питання гармонізації взаємодії людини з довкіллям, шукати шляхи утвердження ідей екоцентризму.

Відправною позицією для нашого дослідження є думка, що в основу екологічної освіти покладено фундаментальну ідею вивчення та осмислення розвитку й цілісності природи, що традиційно розкривається у такому циклі дисциплін, як природничо-наукові. У зв'язку з цим варто зауважити, що, з одного боку, будучи носіями фактично екологічних знань, 
учителі-природничники здатні забезпечити формування екоцентричного типу природорозуміння, однак лише за умови засвоєння ними самими екологічних цінностей, які повинні бути сформовані у процесі їхньої професійної підготовки. 3 іншого боку, як зазначає український науковець Ю. Пелех, «педагогічна наука в нинішньому стані неспроможна запропонувати вчителеві хоча б якийсь із дієвих рецептів подолання прірви між теорією та практикою, оскільки здебільшого послуговується для дослідження педагогічних явищ абстрактними поняттями описового типу» $[10$, с. 34$]$. Тому намагатимемося конкретизувати ідею створення ефективних педагогічних умов для формування екоцінностей у майбутніх учителів природничих дисциплін шляхом аналізу діючих нормативних документів.

Проведений нами спеціальний аналіз освітніх програм щодо підготовки фахівців зі спеціальності 014.15 «Середня освіта (Природничі науки)» першого (бакалаврського) рівня вищої освіти п’яти закладів (Полтавський національний педагогічний університет імені В. Г. Короленка, Ізмаїльський державний гуманітарний університет, Тернопільській національний педагогічний університет імені В. Гнатюка, Уманський державний педагогічний університет імені П. Тичини, Мукачівський державний університет) показав, що аксіологічна складова в освітніх програмах означених закладів представлена мало, а формування екологічних ціннісних компетентностей не $\epsilon$ їх метою. Переконані, що актуалізація екологічних цінностей (а також відповідних їм ціннісних орієнтацій) у суб' єктній позиції майбутніх учителів природничих дисциплін на практиці можлива шляхом створення відповідних педагогічних умов, що охоплюють різні аспекти освітнього процесу, а саме: цілі й завдання, принципи й змістовне наповнення, методи й засоби їхньої реалізації. 3 означеного вище випливає актуальність теоретичного визначення педагогічних умов формування екологічних цінностей у майбутніх учителів природничих дисциплін із подальшим розробленням відповідної педагогічної моделі.

Аналіз наукових досліджень і публікацій. Аналіз сучасних дослідницьких матеріалів педагогічного спрямування дає підстави констатувати про наявність низки методологічних прийомів виокремлення педагогічних умов формування певних компетентностей, а також відповідних методик для їх діагностування. Загальні положення феномену «педагогічні умови» викладено у працях таких авторів, як І. Бахов, А. Литвин, О. Мацейко. Натомість їх конкретизацію та авторське тлумачення знаходимо у дослідженнях О. Блашкової, Н. Грицай, О. Молчанюк та ін. Наукові доробки цих та інших науковців сприяли вирішенню сформульованих нами дослідницьких завдань.

Мета статті - на основі аналізу сучасної теорії та практики професійної освіти виокремити й обгрунтувати педагогічні умови формування екологічних цінностей у майбутніх учителів природничих дисциплін, надати їх змістовну характеристику та окреслити методи реалізації.

Виклад основного матеріалу. Насамперед зауважимо, що для феномену «педагогічні умови» характерне плюралістичне розуміння, що в принципі типово для феноменів предметного поля соиіогуманітарних дисциплін. Означене поняття поширюється на різні аспекти всіх складових освітнього процесу: цілі, зміст, принципи, методи, форми, засоби тощо.
Так, український дослідник I. Бахов трактує «педагогічні умови» як «комплекс взаємодіючих заходів навчально-виховного процесу, що орієнтований на формування певної компетентності та забезпечує перехід на вищий рівень іiї сформованості» $[1$, с. 314]. У вказаному визначенні важливим $є$ інтегративний та комплексний підходи до організації освітнього процесу, акцентування уваги на важливості взаємодії всіх елементів навчального і виховного середовищ, а також залучення компетентнісного підходу, що відповідає сучасним освітнім тенденціям, в основі яких - студентоцентричний підхід, орієнтований на розвиток особистості студента у професійному та універсальному (гуманітарному) сенсах.

Зі свого боку українські науковці А. Литвин та О. Мацейко на підставі грунтовного аналізу методологічних засад поняття «педагогічні умови» вказують на такі варіанти розуміння цього поняття, як: 1) сукупність об'єктивних можливостей вирішення освітніх завдань; 2) сукупність заходів педагогічного процесу; 3) педагогічні вимоги, обставини, за яких компоненти освітнього процесу подані у найкращому взаємозв'язку; 4) сукупність зовнішніх і внутрішніх впливів на навчально-виховний процес; 5) елемент освітньої системи, що конструюється 3 метою досягнення певного результату [6, с. 51]. Крім того, дослідники сформулювали низку типових ознак та положень щодо концепту «педагогічні умови», принципових для розуміння цього феномену. Зокрема, в їхніх наукових студіях відзначено, що «педагогічні умови»: 1) є предметом дослідження методології педагогіки; 2) виражають відношення освітньої системи до навколишніх явищ, без яких вона існувати не може; 3) забезпечують найбільш ефективний перебіг освітніх процесів та явищ; 4) спрямовані на розв'язання освітніх завдань; 5) необхідні для досягнення конкретної педагогічної мети; 6) поєднують суб'єктивне й об'єктивне, внутрішнє і зовнішнє, сутність та явище; 7) забезпечують нормальне (оптимальне) функціонування освітньої системи [6, с. 51]. Виокремлення дослідниками типових ознак та положень щодо концепту педагогічних умов на тлі поліваріантності розуміння цього явища, на нашу думку, свідчить про його багатоаспектність і різноплановість, що обов'язково необхідно враховувати у практиці формулювання педагогічних умов у контексті вирішення конкретних освітніх (навчально-виховних) завдань.

У нашому дослідженні під поняттям «педагогічні умови» ми розумітимемо комплекс навчально-виховних заходів, щзо реалізуються закладом вищої освіти у прочесі професійної підготовки та спрямовані на формування системи професійних компетентностей, розвиток особистості студента у професійному та універсальному (гуманітарному) сенсах. Педагогічні умови, детермінуючи досягнення певних результатів навчання, самі $є$ предметом моделювання освітнього процесу (професійної підготовки) на підставі сучасних освітніх концепцій і технологічних підходів.

Сформувавши загальне розуміння щодо феномену педагогічних умов, $є$ підстави конкретизувати його 3 точки зору вирішення раніше сформульованого нами освітнього завдання: формування екологічних иінностей у майбутніх учителів природничих дисииплін у процесі професійної підготовки. Одразу зауважимо, що професійна підготовка майбутніх учителів природничих дисциплін постає як цілісний, багатокомпонентний процес, певним чином структурований 
і своїм змістом підпорядкований досягненню запланованих результатів навчання - формування професійних компетентностей учителя-природничника (зокрема аксіологічного характеру).

Варто також зауважити, що педагогічні умови формування екоцінностей у майбутніх учителів природничих дисциплін неможливо розглядати відірвано від педагогічних умов здійснення їхньої професійної підготовки, що передбачає формування системи компетентностей та певного рівня професійної педагогічної культури. Освітньо-професійні програми, відповідно до чинного законодавства [11], чітко вказують на те, які саме програмні компетентності загального та фахового характеру мають бути сформовані під час освітнього процесу, а також артикулює програмні результати навчання. Ми вважаємо, що для підвищення обгрунтованості формулювання педагогічних умов формування екоцінностей у майбутніх учителів-природничників варто означити не лише бажані компетентності та програмні результати навчання, а й бажані позитивні зміни в особистості майбутнього вчителя внаслідок формування професійної педагогічної культури, зокрема маємо на увазі зміни ціннісного, когнітивного, дієво-практичного характеру.

Ціннісний компонент професійної педагогічної культури студента $є$ системою цінностей та ціннісних орієнтирів, на підставі яких здійснюється комунікація із зовнішнім світом (передусім у професійній сфері), які детермінують зміст життєвої (зокрема й професійної) стратегії щодо задоволення актуальних життєвих потреб для особистості студента, а згодом учителя-природничника. Когнітивний компонент передбачає володіння знаннями циклу соціогуманітарних дисциплін (філософія, аксіологія, філософія екології, екологічна етика) та знання і розуміння основ природничих наук (фізики, хімії, біології, екології), а також володіння знаннями й розуміння основних понять, законів, концепцій, вчень і теорій природничих наук та еколого-етичних концепцій. Дієво-практична складова професійної педагогічної культури майбутніх учителів-природничників представлена вміннями практичної реалізації здобутих знань циклу соціогуманітарних дисциплін та знань у галузі природничих наук, вимагає практичного використання цих знань у життєвій (зокрема й професійній) практиці, застосування сформованих у процесі професійної підготовки компетентностей у широкому соціокультурному контексті.

Концептуалізуючи педагогічні умови формування екологічних цінностей майбутніх учителів природничих наук у процесі професійної підготовки, ми, очевидно, повинні взяти до уваги те, що стратегічною метою сучасного суспільства (зокрема й педагогічного співтовариства) має стати гармонізація відношення «Людина - Природа». Постає закономірне питання «А що ж є гармонія?».

Зарубіжний дослідник О. Карнишев вказує на те, що гармонія як гармонія внутрішнього і зовнішнього конкретизується в таких відносинах і взаємодіях: а) гармонія всередині фізичного, психологічного та духовного світу людини (коли їй не потрібно в чомусь звинувачувати себе, суперечити самій собі, марно вишукувати виправдувальні аргументи своїм неприродним діям і вчинкам); б) гармонія між людиною і природним середовищем (коли між ними не відчувається дискомфорту в контактах один з одним); в) гармонія між людиною і соціумом із його унікальною культурою, що «прийняв», виростив людину (гармонія, у даному випадку виражається у безкон- фліктній адаптації їх один до одного та до зовнішнього світу) [5, с. 146].

При цьому український дослідник А. Матвійчук вказує на те, що «гармонію потрактовують як стан системи в разі досягнення нею найвищої стадії розвитку, досконалості, функціональної ефективності й продуктивності. Така гармонійна система передбачає механізми забезпечення надійних і продуктивних відносин між людьми, між людиною та соціумом, між соціумом і природою». Принциповим положенням для нашого дослідження у міркуваннях дослідника є обгрунтована ним думка про те, що «сьогодні означені механізми $\epsilon$ продуктом духовного життя людини та суспільства, а їхній характер і ефективність визначається змістом таких форм суспільної свідомості, як мораль, релігія, політика, право, мистецтво та філософія. Іншими словами - змістом культури людини» [7, с. 28]. Із цього випливає, що у змісті педагогічних умов формування екоцінностей у майбутніх учителів природничих дисциплін має бути «прошита» потужна загальнокультурна, зокрема аксіологічна, компонента, тобто йдеться про відповідне наповнення змісту дисциплін, згаданих вище. У контексті обгрунтування педагогічних умов формування екологічних цінностей майбутніх учителів природничих дисциплін вважаємо за доцільне розглянути досвід вирішення питання детермінації педагогічних умов у практиці наукових досліджень на тему вирішення певних освітніх завдань у процесі професійної підготовки. При цьому до уваги бралися дослідницькі праці, близькі за предметом дослідження, - аксіологічно-орієнтовані.

Так, українка О. Блашкова, обравши предметом дослідження проблематику формування гуманістичних цінностей студентів природничих спеціальностей у навчально-виховному процесі педагогічних університетів, обгрунтувала необхідність дотримання певних педагогічних умов гуманістичної спрямованості, а саме: 1) програмно-методичного забезпечення формування гуманістичних цінностей; 2) педагогічної підтримки проявів гуманної ініціативності у навчально-виховній діяльності; 3) сприяння саморозвитку гуманістично-ціннісного орієнтування студентів до довкілля [2, с. 151]. Відзначимо, що підходи дослідниці корелюються із запропонованим нами вище підходом до розуміння педагогічних умов як дихотомії об'єктивного (зовнішні методично-організаційні умови) й суб'єктивного (орієнтація на особистість студента) в освітньому процесі.

Зі свого боку Н. Грицай, вітчизняний фахівець у галузі теорії і методики навчання, опрацьовуючи систему методичної підготовки майбутніх учителів біології в педагогічних університетах, також не оминула завдання визначення педагогічних умов. Зокрема, нею були встановлені педагогічні умови, дотримання яких сприятиме підвищенню якості методичної підготовки майбутніх учителів біології, а саме: 1) формування в студентів позитивної мотивації до виконання методичної діяльності; 2) проєктування змісту методичної підготовки на основі контекстного підходу; 3 ) розроблення і застосування комплексу методичних задач; 4) використання у педагогічному процесі широкого спектра таких організаційних форм навчальної діяльності, як лекції; 5) упровадження інноваційних технологій навчання; 6) формування у закладі вищої освіти індивідуалізованого методично орієнтованого освітнього середовища; 7) створення інноваційного навчально-методичного забезпечення 
дисциплін методичного спрямування [4]. Принциповим для нас моментом у науковій позиції Н. Грицай $\epsilon$ використання у процесі професійної підготовки освітніх технологій розвивального типу, розроблення та системне залучення дидактичного супроводу професійної підготовки, залучення проєктувальних технологій.

Отже, на підставі проведеного вище аналізу й ураховуючи теоретичні здобутки та напрацювання педагогічної науки і практики, узагальнення виявлених недоліків освітніх програм щодо підготовки фахівців зі спеціальності 014.15 «Середня освіта (Природничі науки)» першого (бакалаврського) рівня вищої освіти п’яти згаданих вище закладів, нами були визначені педагогічні умови формування екологічних цінностей майбутніх учителів природничих наук у процесі професійної підготовки: 1) сформованість екоцентричного природорозуміння (через виховання його у майбутніх учителів); 2) усвідомлення екологічних цінностей; 3) внутрішнє прийняття і здатність трансляції та реалізація екологічних цінностей в освітньо-професійній діяльності. При цьому результатом практичної реалізації означених педагогічних умов має стати сформованість екоцентричного природорозуміння, в основі якого засвоєна й усвідомлена майбутнім учителем-природничником система екологічних цінностей (цінність життя в усіх його проявах; природа як самоцінність; цінність гармонії з природою; біоцентризм як відповідальність за світ живих істот; здорове довкілля як цінність; цінність якісного життя (в екологічному дискурсі); цінність екологічних знань; екологічний імідж як цінність), що мають не тільки термінально-позиційний, а й інструментально-поведінковий характер. Додамо, що в контексті нашого дослідження йдеться про педумови, спрямовані на досягнення аксіологічних результатів - сформованості екологічних цінностей у майбутніх учителів-природничників.

Зважаючи на це, розглянемо кожну з виокремлених педагогічних умов детальніше.

1. Сформованість екоцентричного природорозуміння (через виховання його в майбутніх учителів). Засвоєння цінностей особистістю - це досить складний і нелінійний процес, що вимагає тривалих часових затрат. Зміст цього процесу полягає у долученні та формуванні особистого ставлення до складових системи цінностей суспільства, внаслідок чого формується ціннісно-смислова сфера особистості. У ситуації формування цінностей та в контексті професійної підготовки, очевидно, йдеться про процес, організований із точки зору досягнення певних аксіологічних результатів - у нашому випадку формування екологічних цінностей майбутніх учителів природничих дисциплін. До того ж, означений процес має певні часові межі, що визначені обсягом часу, який виділяється на здобуття певного рівня вищої освіти. Така ситуація ускладнює завдання досягнення бажаних аксіологічних результатів (зокрема, формування екологічних цінностей). Утім, відповідні зусилля в освітньому процесі не будуть марними, адже усвідомлення особистістю цінностей сприятиме виникненню системи ціннісних орієнтацій та сформованості ціннісно-смислової сфери як основи життєдіяльності, зокрема професійної. Іншими словами, через ознайомлення й засвоєння екологічних цінностей відкривається шлях до практичної гармонізації відношення «Людина - Природа» як на індивідуальному, так і суспільному рівнях.
Реалізація такої педагогічної умови, як сформованість екоцентричного природо розуміння, передбачає створення індивідуального освітнього маршруту як персонального шляху до екологічних цінностей, їх усвідомлення та прийняття. Крім того, викладач у контексті викладання дисципліни повинен намагатися, аби такий освітній маршрут забезпечував залучення студентів до соціокультурної практики, що забезпечує формування бажаних результатів навчання й виховання: екоцінностей, відповідних ціннісних позицій і внутрішніх імперативів поведінки (життєвої та професійної).

2. Усвідомлення екологічних цінностей. Усвідомлення цінностей для розвитку особистості має принциповий характер. Насамперед це зумовлено тим фактом, що цінності, як було представлено вище, упорядковують дійсність, виступають духовними орієнтирами, адже співвідносяться з уявленнями про певні ідеали, бажане й нормативне. Водночас раніше ми вказували на те, що екологічні цінності постають як єдиний ціннісний блок у системі ціннісних орієнтацій особистості, мають багатовимірний характер і пов'язані з усіма іншими цінностями людини, визначають іiі моральне піднесення, орієнтовані на добро й засвоюються у системі багатоманітних відносин із навколишнім світом.

За таких умов фундаментальною особливістю ціннісного відношення особистості до навколишньої дійсності $є$ те, що воно передбачає добровільне й вільне усвідомлення та дотримання певних цінностей. Крім того, ціннісне відношення не формується силою, воно $є$ внутрішнім та ненасильницьким за своєю природою [3, с. 10]. Зважаючи на це, освітній процес у межах професійної підготовки майбутніх учителів-природничників має бути орієнтований на особистісний та партнерський підходи, створювати умови для ознайомлення з екологічними цінностями, їх розпізнання, осмислення, розуміння, можливості усвідомленого вибору як мірил і норм своїх дій та вчинків. Із практичної точки зору, усвідомлення цінностей, зокрема екологічних, сприяє тому, що самі цінності можуть змінювати свій статус. Маємо на увазі те, що зі статусу цінностей термінально-позиційного характеру (цінності знання й уявлення певного типу) можливий перехід до статусу цінностей інструментально-поведінкового характеру (детермінанти життєвої, зокрема й професійної, поведінки). Лише у цьому випадку екоцінності можуть перетворитися на активну силу, дієвий мотив екоцентричної за змістом поведінки, а ідеї гармонійного єднання із природою набудуть практичного втілення.

Отже, реалізація такої педагогічної умови, як усвідомлення екологічних цінностей, передбачає необхідність створення в освітньому процесі ситуацій, в яких може проявитися ставлення-переживання студентів спеціальності 014.15 «Середня освіта (Природничі науки)» до природи, ii конкретних об'єктів й, водночас, до екоетичних ідей та концепцій, що сприятиме формуванню осмисленої й обгрунтованої ціннісної позиції, екоцентричного природорозуміння. За таких умов до змісту дидактичного матеріалу, на наш погляд, повинні включатися: 1) безпосередня інформація про природу як самоцінність та як цінність духовного й естетичного порядку, необхідність ставлення до неї як ціннісного об'єкта; 2) непряма інформація, що дозволятиме студентам зробити висновок як про цінність особливого порядку про природу 
в усій іiі багатоманітності, а також про іiї закони (екологічні закони); 3) у навчально-методичних матеріалах передбачити завдання, що не лише стимулюють до формування ціннісного відношення до природи, а й сприяють усвідомленню цінностей термінально-позиційного характеру (наприклад, уявлення про природу як самоцінність, визнання цінності гармонії 3 природою) і цінностей інструментально-поведінкового характеру (цінність діяльності щодо забезпечення здорового довкілля, цінність діяльності щодо досягнення якісного життя в екологічному сенсі).

3. Внутрішне прийняття $i$ здатність трансляції та реалізація екологічних цінностей в освітньо-професійній діяльності. Переконані, що внутрішньому, особистісному прийняттю й формуванню здатності трансляції та реалізації екологічних цінностей в освітньо-професійній діяльності сприятиме залучення студентів спеціальності 014.15 «Середня освіта (Природничі науки)» до суспільно корисної, природоохоронної та природозахисної діяльності на добровільних засадах, тобто залучення до екологічного волонтерства. «У ролі інваріантних освітніх технологій залучення і розвитку волонтерства всередині освітньої організації виступають інноваційні проєктні практико-орієнтовані технології «навчання дією», «навчання служінням», «навчання турботі», «навчання творчості», засновані на інтеграції волонтерства 3 освітнім процесом» [9, с. 192]. Волонтерство, з одного боку, покликане сприяти поглибленню процесу осмислення й розуміння екологічних цінностей, а 3 іншого - допомогти студентам отримати емоційний досвід дії, що вмотивована й обгрунтована екоцінностями.

Крім волонтерства, означена педагогічна умова формування екологічних цінностей майбутніх учителів природничих дисциплін ефективно забезпечуватиметься залученням у процес професійної підготовки подієвого підходу як технології організації і здійснення певних подій (у нашому випадку - у ціннісному й екологічному контекстах). Участь у таких подіях, їх організація й проведення створюють додаткові можливості в межах освітнього процесу для інтелектуального й емоційного досвіду студентів, що є додатковим джерелом і стимулом прийняття екоцінностей та відпрацювання здатності трансляції та реалізації таких цінностей в освітньо-професійній діяльності.

Висновки. Отже, зважаючи на викладене вище, вважаємо за необхідне зробити такі висновки й узагальнення:

1. Актуалізація екологічних цінностей (і відповідних їм ціннісних орієнтацій) у суб'єктній позиції майбутніх учителів природничих дисциплін на практиці можлива шляхом створення відповідних педагогічних умов, що охоплюють різні аспекти освітнього процесу: цілі й завдання, принципи й змістовне наповнення, методи й засоби реалізації цілей і завдань освітнього процесу. У зв'язку з цим випливає актуальність теоретичного визначення педагогічних умов формування екологічних цінностей у майбутніх учителів природничих дисциплін із подальшим розробленням педагогічної моделі формування екологічних цінностей у майбутніх учителів-природничників.

2. На підставі викладеного у дослідженні, під поняттям «педагогічні умови» розумітимемо комплекс навчально-виховних заходів, що реалізуються закладом вищої освіти у процесі професійної підготовки, і які спрямовані на формування системи професійних компетентностей, розвиток особистості студента у професійному та універсальному (гуманітарному) сенсах.
Педагогічні умови, детермінуючи досягнення певних результатів навчання, самі $є$ предметом моделювання на підставі сучасних освітніх концепцій та технологічних підходів до навчально-виховного процесу (професійної підготовки). При цьому ми вважаємо, що педагогічні умови, необхідні для формування професійних компетентностей, слід розділити на два блоки: об'єктивні та суб'єктивні умови.

3. На підставі загального розуміння щодо феномену педагогічних умов було концептуалізовано педагогічні умови формування екоцінностей у майбутніх учителів природничих наук. Водночас було враховано, що для підвищення обгрунтованості формулювання педагогічних умов формування екоцінностей у майбутніх учителів-природничників варто означити не лише бажані компетентності та програмні результати навчання, а й бажані позитивні зміни в особистості майбутнього фахівця внаслідок формування професійної педагогічної культури, зокрема маємо на увазі зміни ціннісного, когнітивного, дієво-практичного характеру. Таким чином, на підставі проведеного аналізу нами визначені педагогічні умови формування екологічних цінностей майбутніх учителів природничих дисциплін у процесі професійної підготовки: 1) сформованість екоцентричного природорозуміння (через виховання його у майбутніх учителів); 2) усвідомлення екологічних цінностей; 3) внутрішне прийняття і здатність трансляції та реалізація екологічних цінностей в освітньо-професійній діяльності. Педагогічні умови, реалізація яких веде до успішності даного процесу, можуть і повинні стати частиною вдало змодельованого педагогічного процесу, націленого на ефективну підготовку майбутніх учителів-природничників.

Подалыші дослідження у даному напрямі плануємо спрямувати на пошук та обгрунтування засобів і методів практичної реалізації вказаних педагогічних умов із метою досягнення сформованості екоцентричного природорозуміння, в основі якого - засвоєна й усвідомлена майбутнім викладачем-природничником система екологічних цінностей, які мають не тільки термінально-позиційний характер, а й інструментально-поведінковий. Водночас логіка нашого дослідження зумовлює необхідність спеціального розгляду компонентів, критеріїв, показників та рівнів сформованості аксіологічних компетентностей, зокрема екологічних цінностей майбутніх учителів природничих дисциплін, що сприятиме адекватному розумінню ефективності окреслених нами вище педагогічних умов формування таких цінностей, а також їхнього освітнього (навчально-методичного) потенціалу.

\section{СПИСОК ВИКОРИСТАНОЇ ЛІТЕРАТУРИ}

1. Бахов I. С. Педагогічні умови формування професійно-комунікативної компетентності перекладачів в системі вищої освіти. Вісник Київського начіонального університету ім. Т. Шевченка. Серія «Соціологія. Психологія. Педагогіка». 2009. № 3. С. 313-323.

2. Блашкова О. М. Формування гуманістичних цінностей студентів природничих спеціальностей у навчально-виховномупроцесіпедагогічних університетів: дис. ... канд. пед. наук : 13.00.07. Київ, 2019. 227 с.

3. Выжлецов Г. П. Аксиология культуры. СанктПетербург. : Изд-во СПбГУ, 1996. 152 с.

4. Грицай Н. Б. Система методичної підготовки майбутніх учителів біології в педагогічних університетах : дис. ... д-ра пед. наук : 13.00.02. Полтава, 2016. $526 \mathrm{c}$. 
5. Карнышев А. Д. Природосообразность и психологическое здоровье личности. Сибирский психологический журнал. 2015. № 57. С. 141-156.

6. Литвин А., Мацейко О. Методологічні засади поняття «педагогічні умови». Педагогіка і психологія професійної освіти. 2013. № 4. С. 43-63.

7. Матвійчук А. В. Екологічна деонтологія: філософсько-методологічне осмислення наукових перспектив. Рівне : видав. О. Зень, 2014. 400 с.

8. Молчанюк О. В. Теоретико-методологічні засади виховання в майбутніх учителів біології ціннісного ставлення : дис. ... д-ра пед. наук : 13.00.07. Київ, 2020. 469 с.
9. Николина В. В., Белова Е. А., Говорухина Е. А. Добровольчество в проектной деятельности как фактор духов-но-нравственного воспитания студентов. Культурно-исторические традиции православия : материалы межд. конференции (г. Куремяэ (Эстония) 11-12 декабря, 2014 г.). Куремяэ, 2014. С. 189-194.

10. Пелех Ю. В. Формування вчителя майбутнього: аксіологічний контекст. Інноватика у вихованні. 2017. Вип. 6. С. 34-46.

11. Про вищу освіту: Закон України від 1 липня 2014 p. № 1556-VII. URL: https://zakon.rada.gov.ua/ laws/show/1556-18 (дата звернення: 17.03.2019).

Дата надходження до редакиіï: 23.07.2020 p.
УДК 370.191.12:340.131:616-047

DOI: 10.37026/2520-6427-2020-103-3-153-158
Наталія ХАРЧЕНКО, кандидат педагогічних наук, доиент кафедри природничо-математичної освіти Рівненського ОІППО

\section{ПРАВОВІ ЗАСАДИ ФОРМУВАННЯ КОМПЕТЕНЦІЙ ІЗ ДОМЕДИЧНОЇ ДОПОМОГИ В ПЕДАГОГІЧНИХ ПРАЦІВНИКІВ ЗАКЛАДІВ ЗАГАЛЬНОЇ СЕРЕДНЬОЇ ОСВІТИ}

У статті розглянуто нормативно-правову базу з питань збереження здоров'я людей у критичних для життя ситуаціях немедичними працівниками, зокрема педагогами, які зобов'язані володіти навичками з надання домедичної допомоги дітям. Доведено, щя вмінню надати домедичну допомогу сприяють різні способи навчання осіб, які не мають медичної освіти, але за своїми обов'язками повинні володіти основними практичними навичками щзодо рятування та збереження життя людини, яка перебуває у невідкладному стані.

Ключові слова: домедична допомога, нормативно-правова база домедичної допомоги, практичні навички, особи, які зобов 'язані надавати домедччну допомогу, навчання вчителів, якість домедичної допомоги.

В статье рассмотрена нормативно-правовая база, касаюшаяся вопросов сохранения здоровья людей в критических для жизни ситуациях немедииинскими работниками, в частности педагогами, которые обязаны владеть навыками по оказанию домедииинской помоши детям. Доказано, что умению оказать домедицинскую помощьь способствуют различные способы обучения лии, которые не имеют медииинского образования, но по своим обязательствам должны владеть основными навыками по спасению и сохранению жизни человека, который находится в неотложном состоянии.
Ключевые слова: домедицинская помощь, нормативно-правовая база домедицинской помощи, практические навыки, лица, которые обязаны предоставлять домедииинскую помощьь, обучение учителей, качество домедицинской помощи.

The development of the system of pre-medical aid in Ukraine was analysed from the point of view of the legal framework for pre-medical aid and Concept of quality standards of pre-medical competences of the European Union. The low level of knowledge of pre-medical aid, and as a consequence, deficiencies in the provision of pre-medical aid for participants in the educational process. The author paid attention to solving scientific and theoretical level issues related to the definition of the duties of the pedagogical workers to provide emergency, including pre-medical aid. The subject of research was the need to form algorithms of action practical skills and quality of pre-medical aid.

The analysis of the pre-medical aid regulatory framework has shown the imperfection, inconsistency and contradiction of the regulatory framework in the sphere of civil protection, labor protection and health care. World Health Organization notes that now the optimal model of learning practical skills in the legal field care in the world is not defined: these are trainings, fulltime training, courses, distance learning, self-education, experience exchange. 